Viso - Cadernos de estética aplicada Revista eletrônica de estética

ISSN 1981-4062

No 13, jan-jun/2013

http://www.revistaviso.com.br/

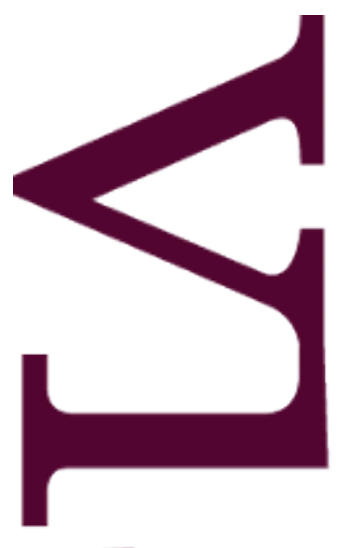

m

r

بn

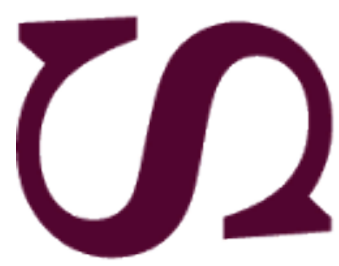

$\varangle$

4

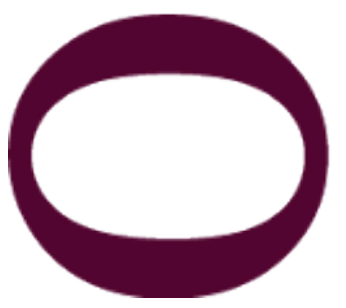

\title{
A literatura entre Derrida e Lacan: dentro/fora das relações de poder Carla Rodrigues
}




\section{RESUMO}

\section{A literatura entre Derrida e Lacan: dentro/fora das relações de poder}

Este artigo discute o uso do termo parergon, que aparece na leitura crítica que o filósofo Jacques Derrida faz do seminário do psicanalista Jacques Lacan sobre sobre o conto " $A$ carta roubada", de E. A. Poe. Derrida se vale desse termo para discutir a maneira como a psicanálise se apropria da literatura, que para Derrida será aquilo que abala todos os limites, com sua qualidade de estar dentro/fora - como um parergon - dos discursos sobre e da verdade. Discute ainda as intrincadas ligações entre a filosofia de Derrida, sua dívida com Freud, e a psicanálise de Lacan.

Palavras-chave: parergon - literatura - verdade - alteridade

\section{ABSTRACT}

\section{The Literature there is between Derrida and Lacan}

This paper discusses the use of the term parergon, which appears in the critical reading by philosopher Jacques Derrida's on the Seminar of psychoanalyst Jacques Lacan about the short story "The Purloined Letter" by E. A. Poe. Derrida makes use of that term to discuss how psychoanalysis appropriates literature, which for Derrida is what shatters all boundaries, with its quality of being inside / outside - as a parergon - of the discourses and the truth. It also discusses the intricate connections between the philosophy of Derrida, his debt to Freud and Lacan's psychoanalysis.

Keywords: parergon - literature - truth - otherness 


\section{RODRIGUES, C. "A literatura entre Derrida e Lacan: dentro/fora das relações de poder". In: Viso: Cadernos de estética aplicada, v. VII, n. 13 (jan-jun/2013), pp. 22- 38.}

DOI: 10.22409/1981-4062/v13i/149

Aprovado: 18.09.2013. Publicado: 29.10.2013.

(C) 2013 Carla Rodrigues. Esse documento é distribuído nos termos da licença Creative Commons Atribuição-NãoComercial 4.0 Internacional (CC-BY-NC), que permite, exceto para fins comerciais, copiar e redistribuir o material em qualquer formato ou meio, bem como remixá-lo, transformá-lo ou criar a partir dele, desde que seja dado o devido crédito e indicada a licença sob a qual ele foi originalmente publicado.

Licença: http://creativecommons.org/licenses/by-nc/4.0/deed.pt_BR

Accepted: 18.09.2013. Published: 29.10.2013.

(C) 2013 Carla Rodrigues. This document is distributed under the terms of a Creative Commons Attribution-NonCommercial 4.0 International license (CC-BY-NC) which allows, except for commercial purposes, to copy and redistribute the material in any medium or format and to remix, transform, and build upon the material, provided the original work is properly cited and states its license. 
Um "prefácio interminável" de um texto que ele ainda viria a escrever. É como o filósofo Jacques Derrida reivindica a ligação entre três de seus livros dos anos 1960 Gramatologia, A escritura e a diferença, A voz e o fenômeno - cujo ponto em comum é o questionamento do signo, tanto na fenomenologia de Husserl quanto na linguística estruturalista de Saussure; forma de indicar que toda metafísica é metafisica do signo, porque todo signo é sempre signo de. ${ }^{1}$ Neste artigo, desenvolvo a hipótese de articulação entre três outros textos de Derrida, estes dos anos 1970. Esporas: os estilos de Nietzsche (1972), O carteiro da verdade (1975), e La vérité en peinture (1978) também poderiam ser um "prefácio interminável" de um livro atravessado pelo debate sobre a questão da verdade, articulada com o problema levantado na década anterior, a crítica ao ideal de presença ao longo da história da filosofia.

Se, como argumenta o psicanalista francês Gérard Wajcman², o século XX é o século dos objetos, e o melhor objeto que representa o século XX é a ruína, Derrida foi um dos pensadores importantes do século das ruínas por ter proposto uma experiência filosófica a partir da desconstrução de algumas categorias do pensamento que até ali restavam intocadas. Nos anos 1960, o movimento de Derrida foi desconstruir o par presença/ausência como parte de um percurso de questionamento das filosofias da consciência - que se desdobrará nas formulações de rastro e différance . Na trilogia dos anos 1970 é o tema da verdade que mobiliza o filósofo. Não que haja nisso uma ruptura. Ao contrário. Essa reflexão é uma continuação da questão da presença, em textos nos quais o debate sobre a verdade se dá a partir de outro par - dentro/fora -, tema aprofundado em La vérité en peinture com a figura do parergon, à qual ele recorre para pensar a verdade, a verdade da arte, problema do desinteresse em relação à obra de arte.

Uma das motivações desse trabalho foi perceber que o termo parergon - amplamente mobilizado no texto de 1978 - já aparece nas primeiras páginas de "O carteiro da verdade", quando Derrida está discutindo as intrincadas relações entre psicanálise e literatura, relações "desde o ínicio marcadas por afetos ambivalentes, ciúme mascarado pela admiração, pulsão de poder revertida em submissão fingida, desejo de apropriação e resistência". ${ }^{3}$ É em torno do parergon que esse artigo se escreve, em consonância com os argumentos da comentadora Ginette Michaud, mas também como forma de dar continuidade a um debate presente em outros trabalhos: a literatura, em Derrida, aparece como aquilo que abala todos os limites, com sua qualidade de estar dentro/fora dos discursos sobre e da verdade. É o argumento que estará em jogo na sua leitura do seminário de Jacques Lacan ${ }^{5}$ sobre "A carta roubada", conto de E. A. Poe ${ }^{6}$, e também o caminho pelo qual ele pensará sua crítica à metafísica como organizada pela hierarquia dos pares presença/ausência, dentro/fora, interioridade/exterioridade. 


\section{Segredos decifrados e decifráveis}

É por falta de uma elaboração do problema do parergon que Derrida percebe, na leitura de Lacan, uma estratégia de "reconstruir a cena do significante em significado (processo sempre inevitável pela lógica do signo), a escritura em escrito, o texto em discurso, mais precisamente: em diálogo 'intersubjetivo'". " "O carteiro da verdade" marcou de tal forma a crítica de Derrida a Lacan e está tão associado aos conflitos entres os dois ${ }^{8}$ que muitos comentadores deixaram em segundo plano a função e o lugar que a literatura ocupa na argumentação de Derrida. No recorte a que me proponho, sigo Michaud, para quem a crítica de Derrida é à estratégia de leitura da psicanálise, identificada por ele como domesticação da literatura em um sistema, forma de ignorar as especificidades da literatura, tão caras ao filósofo. ${ }^{9}$

De fato, muito frequentemente tudo se passa como se a reflexão psicanalítica não levasse suficientemente a sério o que está em jogo na transferência de leitura, como se Ihe fosse possível domesticar (ou arrazoar) a literatura em um teorema psicanalítico sem verdadeiramente levar em conta a especificidade de seus 'efeitos de afeto', ao mesmo tempo fictícios e reais, virtuais e, no entanto, atualizados. ${ }^{10}$

É a partir desta função do literário que Derrida começa "O carteiro da verdade". É esse o recorte que me proponho a seguir aqui, performatizando o problema do parergon ao tentar estabelecer o que está dentro/fora do meu texto.

"A carta roubada" põe em cena o mistério do desaparecimento de uma carta - remetida à rainha -, roubada por seu ministro quando este percebe que a rainha precisa esconder a carta do rei. A trama é contada por um narrador onisciente, que presencia e ao mesmo tempo relata a conversa entre o detetive Dupin e o delegado de polícia encarregado de investigar o roubo da carta. Há uma sucessão de segredos mobilizados na trama de Poe. A rainha sabe que o ministro roubou a carta, o ministro sabe que detém uma carta que a rainha não quer que seja do conhecimento do rei. Há um segredo entre a rainha e o rei, um segredo entre a rainha e o ministro, mas não apenas. O texto de Poe é uma trama de segredos: o segredo sobre o remetente da carta, o segredo sobre o conteúdo da carta, o segredo sobre o paradeiro da carta, o segredo sobre como Dupin fará para desvendar o paradeiro da carta. Segredos que, para Derrida, são inseparáveis da literatura: "O segredo da literatura é, pois, o próprio segredo. É o lugar secreto onde ela se institui como a possibilidade mesma do segredo, o lugar da sua gênese ou de sua genealogia própria". ${ }^{11}$ A literatura será então pensada como lugar de hospitalidade incondicional a esse segredo. ${ }^{12}$

O conto de Poe gira em torno de diversas estratégias de decifração que servirão para Derrida perguntar o que se passa no deciframento psicanalítico de um texto: "A psicanálise se encontra - tudo o que ela encontra - no texto que ela decifra. Mais do que ela mesma. Quais são as consequências disso, quanto à verdade e quanto ao texto?" ${ }^{13}$ 
A mim, parece que uma das consequências que vão interessar a Derrida é a destituição, pela psicanálise, da função da literatura como função de segredo, como indecidível, como aquilo que abala os limites, como lugar de tudo dizer e ao mesmo lugar de não querer dizer. Aqui, evoco uma das mais interessantes definições de literatura propostas por Derrida:

a literatura não é uma instituição como outras: ela é ao mesmo tempo instituição e contrainstituição, colocada à distância da instituição, no ângulo que a instituição faz com ela mesma para se afastar dela mesma. E, aos meus olhos, se a literatura guarda aqui algum privilégio, é em parte em razão do que ela tematiza sobre o acontecimento da escritura e, de outra parte, disso que, na sua história política, a liga a essa autorização de a princípio "tudo dizer", que a relaciona de forma única a isso que se chama a verdade, a ficção, o simulacro, a ciência, a filosofia, a lei, o direito, a democracia. ${ }^{14}$

O argumento, esboçado nessa entrevista de 1990, será aprofundado dois anos depois, em outra entrevista, desta vez nos EUA, quando Derrida diz a Derek Attridge que "a literatura é a coisa mais interessante do mundo, talvez mais interessante que o mundo". ${ }^{15}$ Com a função de questionar a autoridade e a pertinência da pergunta "o que é", a literatura será para o filósofo uma estratégia de abalo de qualquer autoridade metafísica. $\mathrm{Ou}$, retomando os termos iniciais, na literatura o signo não é necessariamente signo de. No entanto, como Derrida percebe, na leitura de Lacan para "A carta roubada", a psicanálise pretende dizer a verdade do texto literário, a verdade da carta, a verdade do sujeito. Três hipóteses, três problemas.

\section{O problema formal}

Estão condensadas em três páginas de "O carteiro da verdade" as críticas que Derrida destina ao problema da apropriação por Lacan do texto literário. Ele começa indicando a exclusão do narrador e articulando a neutralização do lugar do narrador com a maneira como Lacan promove "uma leitura fascinada" do conteúdo do texto ficcional. Por isso, observa que Lacan começa seu texto delimitando o que está dentro e o que está fora de sua leitura, quando diz: "Essas cenas são duas". ${ }^{16}$ Fica de fora, portanto, a terceira cena, que é a narrativa das duas cenas - a do roubo da carta e a da procura pela carta.

O lugar original do narrador dos dois lados da narrativa, o estatuto específico de seu discurso - que não é neutro ou cujo efeito de neutralidade não é neutro -, suas intervenções, sua própria posição psicanalítica jamais serão interrogados na continuação do Seminário [...]. Todas as alusões ao narrador e ao ato de narração estão ali para excluí-los do 'drama real' (as duas cenas triangulares) que é preciso entregar, assim, nitidamente delimitado, ao decriframento analítico da mensagem. ${ }^{17}$

Dois aspectos dessa citação me interessam.

Primeiro, a referência às duas cenas triangulares. Há um primeiro triângulo - o rei, a rainha e o ministro, personagens que se organizam em torno da posse da carta. Há um 
segundo triângulo - o narrador, Dupin e o delegado, personagens que se organizam em torno da decifração da posse da carta no primeiro triângulo e performatizam aquilo mesmo que se dá na primeira narrativa, a posse da informação sobre quem tem a carta. Há um terceiro triângulo, entre o narrador, o autor e o leitor, que desaparece se excluirmos a figura do narrador para fazer apenas uma leitura formal. E há, por que não, um triângulo que se forma entre Derrida, Lacan e Poe, mobilizados no texto de Derrida em torno da discussão sobre a verdade da carta, mais uma camada entre as muitas estratégias de poder sobrepostas: a que mobiliza a disputa entre o rei, a rainha e o ministro; a que mobiliza o narrador e os dois investigadores; a que mobiliza o narrador, o leitor e a busca pela carta. Ou seja, em relação à verdade da carta há diferentes estratégias de poder das quais a leitura de Lacan e a leitura de Derrida também fazem parte. No texto de Poe, no qual tudo se passa como metáfora da impossibilidade de se alcançar o conteúdo de um texto; na leitura de Lacan do texto de Poe, denunciada por Derrida como uma forma de a psicanálise instrumentalizar a literatura a serviço da busca da verdade; na leitura de Derrida para o texto de Lacan, destinada a esvaziar o discurso da psicanálise de uma potência de verdade sobre a literatura (é claro que todo texto, inclusive este, que pretenda analisar o texto de Derrida performatiza mais uma estratégia de poder, numa cadeia infinita).

Se o conto de Poe pode ser lido como uma forma de representação de estratégias de poder esvaziadas de conteúdo - desde que organizadas em torno de um segredo que mobiliza os atores independentemente do que está dentro/fora da carta - , a leitura de Lacan seria, para Derrida, uma forma de limitar o jogo da disseminação desta carta.

Em segundo lugar, interessa-me observar na citação o problema da neutralidade do narrador literário, parte de um diálogo entre Derrida e Maurice Blanchot. ${ }^{18} \mathrm{O}$ filósofo segue os passos de Blanchot no questionamento da neutralidade da voz do narrador, neutralidade que encarnaria o neutro da voz do saber - filosófico, psicanalítico -, neutralidade de um saber sem limites, sem restrições, sem contaminação por qualquer experiência de não saber. Recupero os argumentos de Derrida sobre os problemas que decorrem do que ele considera a neutralização proposital do narrador na leitura de Lacan e que se articulam, como veremos, com a questão do parergon.

1) Lacan, argumenta Derrida, exclui a ficção textual formada pelo triângulo entre o narrador, Dupin e o delegado para se concentrar no que ele chama de "drama real", que se passa entre o rei, a rainha e o ministro. Essa exclusão, ainda segundo Derrida, indica um problema de parergon, de moldura, de borda, de delimitação. Ou, em outras palavras, é um problema de distinguir o que está dentro/fora da ficção textual, do texto de Poe como objeto de análise. Derrida aponta esta exclusão como parte do "esforço de deciframento". 
2) Lacan, também argumenta Derrida, teria ignorado a estrutura formal do texto, operação que permitiria realizar o seu trabalho interpretativo, fazendo com que esse formalismo garanta "o recorte sub-reptício de um contéudo semântico do texto".

3) Esse enquadramento feito por Lacan, enquadramento que ignoraria a estrutura formal do texto, o lugar do narrador e o triângulo formado por este, Dupin e o delegado seria uma forma de violência da leitura lacaniana em nome da verdade do texto. ${ }^{19}$

Em resumo, essa primeira crítica de Derrida a Lacan está ligada ao enquadramento, que ignoraria a estrutura formal do texto a fim de fazê-lo operar segundo um desejo de apropriação, em uma relação de autoridade que, no limite, seria incoerente com o discurso psicanalítico. É a partir da percepção derridiana de que Lacan separa o dentro/fora da obra de Poe que me interessa chegar ao debate sobre o parergon em La vérité en peinture.

\section{Três passos atrás: Kant, Nietzsche e Heidegger}

Depois da Crítica da razão pura (1781), teórica e dedicada à faculdade do conhecimento; da Crítica da razão prática (1788), que pensa a faculdade da vontade como regulada pela autonomia da vontade, Kant se debruça sobre a faculdade de julgar, cuja primeira característica, anunciada desde o prólogo, é conciliar a faculdade de conhecer com a faculdade de desejar. A faculdade de julgar deve promover, segundo Kant, uma síntese, deve funcionar como o "termo médio" - para usar a expressão da introdução na tradução brasileira - entre entendimento e razão. A faculdade de julgar fornece um a priori, que será a fonte do juízo reflexionante, com o qual somos capazes de julgar se um objeto é belo. Kant estaria assim apontando para o fato de que o sujeito possui um conjunto de capacidades cognitivas regulado por princípios a priori que não poderiam ser pensados nem do ponto de vista prático nem teórico, fazendo com que o juízo de gosto não possa ser classificado nem como um juízo de conhecimento nem como juízo moral. O juízo do gosto exige que deixemos que o objeto que vem ao nosso encontro se apresente para nós puramente como ele mesmo, em sua estatura e dignidade. $\mathrm{O}$ belo kantiano exigirá ser honrado de modo puro em sua aparência, a partir de algumas condições: 1) a de um juízo que esteja assentado sobre uma manifestação subjetiva de prazer e desprazer, como juízo do gosto; 2) é um predicado que postula a concordância dos interlocutores. Assim, belo é aquilo que agrada sem interesse, que pode ser compreendido sem ser conceituado ou, como observa Caygiil ${ }^{20}$, é um conceito negativo. O que permite ao juízo sobre o belo postular validade universal é o fato de que seu fundamento de prazer/desprazer é posto na forma do objeto, na sua aparência, e não na sensação produzida pelo objeto.

$\mathrm{O}$ argumento da exigência do desinteresse como aquilo que permite o julgamento do belo tem sido amplamente discutido por comentadores. Não se pretenderá, aqui, mais 
uma leitura do tema kantiano, mas apenas uma breve contextualização de um dos debates que se estabeleceu, a partir da leitura de Nietzsche e Heidegger. ${ }^{21}$ Nietzsche foi um importante crítico de Kant, e grande parte de sua obra é um debate com o kantismo e, principalmente, com o neokantismo em vigor em sua época. No que diz respeito ao problema do desinteresse no juízo do belo, a crítica de Nietzsche se refere ao fato de que, embora Kant tenha tentado "prestar honras à arte", ao conferir ao belo as qualidades de impessoalidade e universalidade, teria pensado o problema estético a partir do espectador, e não do criador, tendo, assim, incluído o espectador no conceito de belo. Nietzsche se voltará contra a proposta kantiana da falta de interesse necessária ao espectador para que ele julgue a obra de arte como bela e dirá que Kant empobreceu a arte, criando o "homem do bom gosto", aquele que admira as obras de arte nos museus sem Ihes atribuir nenhuma potência, esvaziando, assim, o "estado de embriaguez" ao qual a obra de arte deve nos elevar. ${ }^{22}$

Nos cursos dedicados à obra de Nietzsche, Heidegger sustenta que Nietzsche não entendeu a proposição kantiana de desinteresse. Heidegger defende Kant, em primeiro lugar reconstituindo seus argumentos: o desinteresse em Kant não teria a ver com indiferença. Se o juízo do tipo "isso é belo" exige de nós desinteresse, diz Heidegger, quer dizer que "precisamos deixar aquilo mesmo que vem ao nosso encontro vir até diante de nós puramente como ele mesmo, em sua própria estatura e dignidade". Em outras palavras, desinteresse quer dizer, na compreensão de Heidegger, que não podemos pretender gozo, vantagem, ou ter em relação ao objeto metas e objetivos: "Precisamos liberar o que vem ao encontro como tal no que ele é, deixar e permitir-lhe alcançar o que pertence a ele mesmo e o que ele pode trazer para nós". Concordando com Kant, Heidegger também defenderá que só a partir do desinteresse podemos honrar o objeto artístico pelo que ele é, na forma pura de sua aparência. Esta atitude depende de um "empenho supremo da nossa essência para a reconstituição livre do que tem uma dignidade própria em $\mathrm{si}^{2}{ }^{23}$

\section{O problema do parergon}

É nesta discussão que Derrida ${ }^{24}$ desembarca em La vérité en peinture, texto no qual ele vai seguindo linha a linha a primeira parte da Crítica da faculdade do juízo para discutir a proposição kantiana da faculdade de julgar como termo médio entre as faculdades de conhecer e de desejar, até chegar ao problema que me interessa aqui: a ligação entre o belo e o desinteresse e suas consequências para o julgamento do objeto artístico. Como leitor de Nietzsche e de Heidegger, Derrida não se alinha nem a um nem a outro no debate que já havia se estabelecido entre os dois a respeito do problema do interesse/desinteresse da obra de arte, justamente por se interessar nem pelo dentro, nem pelo fora, mas pelo embaralhamento dessa distinção. Sua posição será interrogar quais são as condições de possibilidade de uma atitude desinteressada diante da obra de arte que se dê a partir da clara delimitação entre dentro/fora. Assim, não se tratará 
mais de discutir, como em Nietzsche, se o desinteresse esvazia a potência da arte; ou como em Heidegger, se o desinteresse é aquilo mesmo que dignifica a arte. Ao discutir quais são as possibilidades do juízo desinteressado tal qual pensado por Kant, Derrida deslocará a questão para pensar como delimitar aquilo que está dentro ou fora da obra de arte. Para isso, se vale do termo parergon, palavra com a qual quer se referir a um fora da obra que participa da obra, ao suplemento. Como a moldura de um quadro, exemplo que ele usa a partir do termo grego parerga, aqui entendido como ornamento, e do qual Kant se vale para falar daquilo que "não pertence à inteira representação do objeto internamente como parte integrante, mas só externamente como acréscimo". ${ }^{25}$ Parergon funciona também como suplemento, e portanto se articula com o problema da origem, do originário, do natural e sua contraposição ao artifício.

Se em Kant o julgamento estético deve ser desinteressado, a questão para Derrida passa a ser saber se eu posso dizer de uma coisa se ela é bela sem ter, intrinsecamente, nada a ver com o interesse que eu carrego ou não sobre sua existência. Derrida dirá que este tipo de distinção kantiana - entre o que confere valor à beleza e o que resta externo ao sentido imanente de beleza - organiza todos os discursos filosóficos sobre arte, que pressupõe um discurso sobre o limite entre o dentro e o fora do objeto artístico. $O$ parergon será então aquilo que embaralha o intrínseco/extrínseco à obra, é a borda, o limiar instável entre dentro/fora, e não será apenas a moldura de um quadro, como no exemplo da parerga de Kant, mas a indicação de como o discurso da tradição filosófica se organiza também sobre o par dentro/fora, interior/exterior.

É através da leitura de Kant que Derrida chegará a uma formulação sobre a arte, sintetizada por Jean Luc Nancy: não se trata nem de falar sobre arte, nem de fazer a arte falar, mas de reconhecer a impossibilidade de se fazer a distinção dentro/fora da arte. . Trata-se de pensar que "há arte", ou seja, de apontar para o que há de irredutivelmente outro na obra de arte, aquilo que não pode ser classificado nem como sujeito nem como objeto. Com este discurso, ele pretenderá "preservar a autossuficiência da obra de arte" $^{\prime 26}$, recusando tanto um discurso que pretenda fazer a arte falar, quanto uma estética negativa. Trata-se então de resguardar à arte um lugar totalmente outro, um lugar em que o irrepresentável permaneça irrepresentável. Não se tratará, portanto, de decifrar o "segredo da arte", mas de permanecer como resto, como "restância", o que será, para Derrida, uma forma de lidar com a arte a partir de "restos impensados, parergons e outros subjéteis". ${ }^{27}$

Ele abre os ouvidos da filosofia e isso quer dizer que ela se torne atenta aos timbres, ritmos, cadências, danças e traços, trações, rasuras, toques ou sinais que estão fora, que são seus outros e cuja alteridade não pode ser reconhecida e aproximada se não que se tome distância respeitosa e protegida do domínio do discurso. ${ }^{28}$

Derrida argumentará que não se poderá mais nem fazer a arte falar - como teria pretendido a psicanálise -, nem falar sobre arte, nem fazer da arte o lugar de representar o irrepresentável. Para ele, a única atitude à altura da arte é se manter "ao redor" da arte, 
"em torno" da arte. Por esse caminho, se poderá articular estética e ética no pensamento de Derrida, como propõem alguns comentadores que mobilizo nesse texto ${ }^{29}$ e como discuto em outros lugares. ${ }^{30}$ Trata-se então de deslocar o debate sobre a verdade - da literatura, da psicanálise - para o debate sobre o dentro/fora de um texto, de todo texto, a partir da qual, ainda seguindo o argumento de Michaud, a obra literária e a obra de arte trazem uma instância ética,

sem que a literatura e a arte sejam nunca nelas mesmas assujeitadas a um ato moral; que ela permaneça sendo o horror mais tenaz da literatura, da arte e, do outro lado, do comentário ligado a ela, esta não é uma sombra de uma dúvida: todos os escritos de Derrida sobre a arte começam a 'falar de arte' a partir desse ponto - certamente sem apoio, mas o único que estaria para ele à altura da obra. ${ }^{31}$

Esse ponto sem apoio é o que me permite articular o tema da verdade que, assim como já havia acontecido com o tema da presença, aparece em Derrida posta em abismo, como ele propõe em Esporas: os estilos de Nietzsche. Nesse texto, a partir da leitura que ele faz de Nietzsche e do gesto nietzschiano de suspender a "verdade" entre aspas, Derrida propõe a suspensão, entre aspas, de todos os conceitos filosóficos e a ampliação do questionamento da verdade não mais como articulada apenas à mulher ou ao feminino, como havia feito Nietzsche, mas também ao masculino. Derrida faz essa ampliação desconstruindo a pretensão de propriedade que haveria no masculino e mostrando que só o que há é o suplemento de origem, nunca a origem. ${ }^{32} \mathrm{~A}$ questão do suplemento se articula com o problema do parergon, aqui pensado como aquilo que, estando fora da obra, suplementa a obra, e não fazendo parte da interioridade da obra, embaralha a distinção dentro/fora. É a partir deste ponto sem apoio que, de forma também triangular, os textos de Derrida mencionados no início deste trabalho se articulam na discussão sobre a verdade.

\section{O problema do próprio}

Depois da crítica à apropriação da psicanálise pela literatura, Derrida desdobrará sua leitura em muitas questões. A que me interessa aqui é o problema da verdade como o que, ligando a trilogia de textos a que me referi anteriormente, marcará a diferença entre Derrida e o estruturalismo. Por isso, penso que "O carteiro da verdade" não pode ser lido fora das críticas Derrida à insistência, no pensamento estruturalista, em um ideal de centro, de origem, que limita o jogo das estruturas, limita como um parergon que pretende delimitar o que está dentro/fora da obra de arte, limita como Lacan pretende limitar as possibilidades de circulação da carta. A verdade sobre o texto "A carta roubada" aparece como um problema sobre o lugar e o sentido próprio da carta, mas não pode ser lido apenas dentro de uma discussão sobre a verdade de um texto, encontrados por Dupin, na narrativa de Poe, e por Lacan, no seminário. 
Lacan nos reconduz em direção à verdade, em direção a uma verdade que não se perde. Ele reconduz à carta, mostra que a carta se reconduz a seu lugar próprio por um trajeto próprio e, como o nota expressamente, é essa a direção que Ihe interessa, o destino como direção. O significante tem seu lugar na carta e esta última reencontra seu sentido próprio em seu lugar próprio. Uma certa reapropriação e uma certa readequação vão reconstituir o próprio, o lugar, o sentido, a verdade distanciados deles mesmos pelo tempo de um desvio ou de um sofrimento. ${ }^{33}$

Derrida reconhece que Lacan não atribui à carta um significado, mas dirige sua crítica ao fato de que o Seminário de Lacan esteja voltado a mostrar o significante/carta em "um lugar e um sentido próprios que formam a condição, a origem e a direção de toda a circulação, assim como de toda a lógica do significante". ${ }^{34}$ No que diz respeito à lógica do significante, Derrida retomará também a crítica que havia feito à linguística estruturalista de Saussure, cuja proposição sobre a linguagem representava uma tentativa - para Derrida, insuficiente - de romper com o sentido. O sistema da língua proposto por Saussure pensa a linguagem como fenômeno social, com regras que se estabelecem e se constituem à revelia do sujeito. Derrida percebe que, embora haja, por parte de Saussure, uma ruptura com o ideal metafísico de sentido no reconhecimento de que a ligação entre significante e significado é arbitrária, a linguística estruturalista ainda se manteria como um sistema totalizante, que pensa a linguagem como capaz de conferir sentido a qualquer termo, e ainda presa à hierarquia entre fala e escrita que organizou a história da metafísica, de Platão a Heidegger, passando por Aristóteles, Rousseau, Hegel e Husserl, por exemplo. O privilégio da phoné, o "estranho privilégio do som na idealização, na produção do conceito e na presença a si do sujeito" ${ }^{35}$, se manteria tanto na linguística de Saussure quanto no privilégio conferido por Lacan ao significante. Derrida o percebe ao apontar a "co-implicação, no discurso lacaniano, entre a verdade e a fala, a fala 'presente', 'plena' e autêntica". ${ }^{36}$

É aqui que posso retomar o que anunciei no início: a articulação entre a questão da verdade e a questão da presença. Verdade e presença formam, no pensamento de Derrida, um triângulo cujo terceiro vértice é a questão da propriedade, do próprio, que também se articula com o problema do parergon, aqui entendido como suplemento. Quando contesta a leitura de Lacan, o filósofo aponta a identificação de um trajeto próprio que restringe a circulação da carta. O problema, então, não é apenas que ela volte ao destino, mas que ela sempre volte ao seu destino.

No sempre, haveria no estruturalismo ainda um ideal de manter sob controle o jogo do significante, organizado a partir de um centro que

podendo igualmente estar fora e dentro, recebe indiferentemente os nomes de origem ou fim, de arquê ou de télos, as repetições, as substituições, as transformações, as permutas são sempre apanhadas numa história do sentido - isto é, simplesmente uma história - cuja origem pode sempre ser despertada ou cujo fim pode ser antecipado em forma de presença. ${ }^{37}$ 
Observo como Derrida identifica que o ideal estruturalista de centro pode estar ao mesmo tempo dentro fora e dentro - como um parergon - mas ainda assim sustenta os ideais de presença, verdade e propriedade, que também aparecem na proposição de que uma carta volte ao seu destino, ao seu lugar próprio, garantido e garantidor da verdade. Que seja a verdade do significante/carta é, para Derrida, insuficiente, e foi também em torno do significante que as diferenças entre ele e Lacan se organizaram. ${ }^{38}$ Que a carta circule, mas tenha sua circulação restrita na leitura do psicanalista, é para Derrida uma indicação dos limites do jogo do estruturalismo, ainda ordenado a partir de um centro que circunscreve as possibilidades de circulação da carta. Por isso, argumento que Derrida não está apenas pretendendo proteger a literatura ou o discurso literário como aquilo que escapa a toda conceitualização, mas também pretendendo proteger a psicanálise de sua adesão ao estruturalismo - alvo implícito de sua leitura do texto de Lacan.

\section{Dentro/fora das relações de poder}

Assim como Lacan, ainda que muitos anos depois, Derrida foi um pensador que propôs um retorno a Freud. Se menciono o retorno a Freud é por dois motivos: no primeiro, sigo o argumento de Hurst, para quem Lacan e Derrida são como dois irmãos, e "ambos matam e recuperam o pai Freud, reinventando-o"39; em segundo lugar, por achar que no que diz respeito ao uso que a psicanálise fez, e em alguns casos ainda faz, da literatura, é importante observar que "O carteiro da verdade" começa com uma crítica a Freud. Há pelo menos duas camadas de leitura às críticas de Derrida: na primeira, o filósofo parece mobilizado a preservar o literário, não como "puro", mas como lugar de não verdade, como o que não pode ser objeto de apropriação em qualquer teoria do conhecimento organizada pela relação sujeito/objeto ou mesmo pela intersubjetividade fenomenológica, como tentei apresentar até aqui. Escritura e literatura aparecem como lugar de não verdade, como aquilo que escapa, que não tem identidade ou autoidentidade. Ao trazer a psicanálise para a filosofia, Derrida mobiliza Freud como um autor que ensina a filosofia a desconfiar desses três pontos de apoio da tradição metafísica: presença, verdade, próprio. Na sua crítica a Lacan, Derrida associa o psicanalista e o estruturalismo a estas três categorias da tradição metafísica.

Mas em sua trajetória filosófica faz sua inscrição em seu lugar de retorno a Freud, personagem oculto em "O carteiro da verdade", salvo as referências iniciais sobre como o psicanalista também soube se valer da verdade da literatura. Se Derrida trouxe a psicanálise para a filosofia, pode-se dizer que Lacan levou a filosofia para a psicanálise, em movimentos de embaralhamento entre o que está dentro/fora destes dois campos, e que em muito pode explicar as relações de conflito e as disputas de poder entre os dois pensadores. Na crítica de Derrida às filosofias da consciência - decisiva para o desdobramento da sua obra -, Freud foi o autor a quem ele recorreu a fim de se deslocar da definição clássica de transcendental para quase transcendental, que se abre a "um 
regime de disseminação que fragiliza a identidade do sujeito e a do objeto". ${ }^{40}$ Freud dará ao filósofo uma chave de leitura para um diálogo com a fenomenologia e tudo aquilo que, na leitura de Derrida, este pensamento ainda comandava em um ideal de presença. ${ }^{41}$ Como também observa Hurst, a partir de Freud, a psicanálise serviu à filosofia como argumento para a desconstrução do privilégio da presença. ${ }^{42}$ Lacan, desde o "Discurso de Roma", em 1953 - e portanto anos antes de Derrida - terá suas razões de retorno a Freud. Fará disso um grande movimento ético-político que tornará sua abordagem psicanalítica um tipo de discurso que pretende "reabrir as capacidades do sujeito" ${ }^{43}$, a fim de "elevar a impotência ao impossível"". ${ }^{44}$

Mas se, na perspectiva lacaniana, jamais será possível uma ligação perfeita entre sujeito e objeto, se, na perspectiva derridiana, a ligação sujeito/objeto também está inexoravelmente marcada pela différance - aqui no sentido de um diferimento infinito - , onde estaria, então, o desencaixe entre Derrida e Lacan? Se retornarmos à importância de Freud no pensamento de Derrida, podemos pensar que o desencaixe entre Derrida e Lacan está dentro da crítica às relações de poder da psicanálise sobre a literatura, mas não está fora da crítica do filósofo ao estruturalismo do qual Lacan foi um dos grandes expoentes, está dentro das intrincadas relações de poder entre a filosofia e a psicanálise - com Lacan fazendo uma psicanálise da filosofia e Derrida fazendo uma filosofia a partir da psicanálise - , mas não está fora de uma disputa por uma carta-testamento de Freud.

\footnotetext{
* Carla Rodrigues é professora adjunta do Departamento de Filosofia da UFRJ e pesquisadora, sob a supervisão de Fabio Durão, na IEL/UNICAMP, do Programa de PósDoutorado Júnior do CNPQ (2011/2013), projeto do qual este artigo faz parte.
}

1 SAFATLE, V. "Être juste avec Freud". In: MANIGLIER, P. (org.) Le moment philosophique des années 1960 en France. Paris: PUF, 2011.

2 WAJCMAN, G. "A arte, a psicanálise, o século". In: Lacan, o escrito, a imagem. Tradução de Yolanda Vilela. Belo Horizonte: Autêntica, 2012.

${ }^{3}$ MICHAUD, G. "Psicanálise, literatura, desconstrução: o impossível em partilha". In: MAJOR, R. Estados Gerais da Psicanálise. Rio de Janeiro: Contracapa, 2003, p. 115.

${ }^{4}$ Refiro-me a outros dois artigos desta pesquisa de pós-doutorado. RODRIGUES, C. "Paixões da literatura: ética e alteridade em Derrida". In: Revista Sapere Aude, PUC-Minas, 2013b; "Como se fosse literatura, como se não fosse filosofia: questão de estilo". In: Revista Aisthe, UFRJ, 2013c [prelo].

${ }^{5}$ LACAN, J. Escritos. Tradução Vera Ribeiro. Rio de Janeiro: Zahar, 1998.

${ }^{6}$ POE, E. A. A carta roubada e outras histórias de crime e mistério. Porto Alegre: LP\&M, 2003.

7 DERRIDA, J. "O carteiro da verdade". In: . O cartão-postal: de Sócrates e Freud e além. Tradução de Ana Valéria Lessa e Simone Perelson. Rio de Janeiro: Civilização Brasileia, 2007, p. 478.

${ }^{8}$ PEETERS, B. Derrida. Tradução de André Telles. Rio de Janeiro: Civilização Brasileira, 2013. 
${ }^{9}$ MICHAUD, G. "Jacques Derrida e a questão das artes, ou como aprender a ver de outra forma". Tradução de Piero Eyben e Fabrícia Walace Rodrigues. In: EYBEN, P.; RODRIGUES, F. (orgs). Derrida, Escritura \& Diferença no limite ético-estético. Vinhedo: Horizonte, 2012; Tenir au secret (Derrida, Blanchot). Paris: Galilée, 2006; "Psicanálise, literatura, desconstrução: o impossível em partilha". Op. cit.

${ }^{10}$ Idem, "Psicanálise, literatura, desconstrução: o impossível em partilha". Op. cit., p. 122.

11 DERRIDA, J. Gêneses, genealogias, gêneros e o gênio. Tradução de Eliane Lisboa. Porto Alegre: Sulina, 2005, p. 22

12 Idem. Demeure: Maurice Blanchot. Paris: Galilée, 1998.

${ }^{13}$ Idem. "O carteiro da verdade". Op. cit., p. 465.

${ }^{14}$ Idem. "An interview with Jacques Derrida”. In: Acts of literature. New York and London: Routledge, 1992, p. 357.

${ }^{15}$ Título do projeto de pós-doutorado que inspira essa pesquisa.

${ }^{16}$ LACAN, J. Escritos. Tradução Vera Ribeiro. Rio de Janeiro: Zahar, 1998, p. 14.

${ }^{17}$ DERRIDA, J. Op. cit., p. 475.

${ }^{18}$ DERRIDA, J. Demeure: Maurice Blanchot. Op. cit.

${ }^{19}$ DERRIDA, J. “O carteiro da verdade". Op. cit., pp. 477-479.

${ }^{20}$ CAYGILL, H. Dicionário Kant. Tradução de Álvaro Cabral. Revisão técnica-normativa de Valério Rohden. Rio de Janeiro: Jorge Zahar Editor, 2000.

${ }^{21}$ HEIDEGGER, M. Nietzsche. Tradução de Marco Antônio Casanova. Rio de Janeiro: Forense Universitária, 2007. v. I.

${ }^{22}$ NIETZSCHE, F. Genealogia da moral. Tradução de Paulo César de Souza. São Paulo: Cia. das Letras, 1998. Terceira dissertação, § 6 .

${ }^{23}$ HEIDEGGER, M. Nietzsche. Op. cit., p.100.

${ }^{24}$ Tenho trabalhado com a hipótese de que uma das heranças que Nietzsche deixa a Derrida é a confrontação com a obra de Kant. Derrida foi um leitor de todo o arcabouço teórico de Kant, e seus trabalhos se referem, direta ou indiretamente, ao filósofo das Luzes. No que diz respeito a este artigo, me interessa indicar a relação que Derrida estabelece com a Crítica da faculdade do juízo, sobre a qual escreve La vérite en peinture. Em relação ao conhecimento, Derrida não enfrenta Kant diretamente, mas a partir de dois caminhos: o primeiro, nietzschiano, de questionamento da verdade na filosofia. Aponto aqui principalmente "Esporas: os estilos de Nietzsche", texto no qual Derrida está partindo do gesto de Nietzsche de suspender a verdade entre aspas para suspender entre aspas todos os conceitos filosóficos. O segundo caminho de diálogo com a Crítica da razão pura é pela leitura da fenomenologia de Husserl, marca de seus primeiros trabalhos filosóficos, ainda nos anos 1960, quando Derrida contesta o apelo fenomenológico de "volta às coisas mesmas" com o "a coisa mesma sempre escapa". Em relação à Crítica da razão prática, Derrida também herda de Nietzsche o questionamento da responsabilidade moral tal qual pensada por Kant. Seu texto mais diretamente voltado para o problema da ética é "Donner la mort", no qual discute pontos muito específicos do corpus kantiano, como a autonomia da vontade e o agir moral por dever. Derrida foi também um importante leitor das obras políticas de Kant, leitura que marca o que muitos comentadores chamam de "segundo Derrida". Sua proposição de hospitalidade incondicional se constrói a partir da leitura das condições da hospitalidade em Kant. Outros temas caros a Kant também foram explorados por Derrida, em títulos que fazem referência diretamente a Kant. Em "Fé e saber: as duas fontes da 'religião' nos limites da simples razão", Derrida está interrogando as possibilidades de separação entre razão e religião - condições que Kant afirmara no seu "A religião nos limites da simples razão". Em "Le 'monde' des lumières à venir", ele está se 
confrontando com as afirmações de Kant sobre "O que é o lluminismo?". Em "Du droit à la philosophie", ele volta ao "Conflito das faculdades" para retomar as proposições kantianas sobre o lugar da filosofia na universidade moderna.

${ }^{25}$ KANT, I. Crítica da razão prática. Tradução de Valério Rohden. São Paulo: Martins Fontes, 2011, p. 72 .

26 NANCY, J.-L. "Éloquentes rayures". In: JDEY, A. (org.) Derrida et la question de l'art: déconstructions de l'esthétique. Nantes: Cécile Defaut, 2001, p. 16.

${ }^{27}$ MICHAUD, G. "Jacques Derrida e a questão das artes, ou como aprender a ver de outra forma". Op. cit., pp. 12-13.

${ }^{28}$ NANCY, J.-L. Op. cit, p.17.

${ }^{29}$ MAUGUIT, G. "L'esthétique du bien-dire". In: ROELENS, N. Jacques Derrida et l'esthétique. Paris: L'Harmattan, 2000. MICHAUD, G. "Psicanálise, literatura, desconstrução: o impossível em partilha". Op. cit.;Idem. Tenir au secret (Derrida, Blanchot). Op. cit.;Idem. "Jacques Derrida e a questão das artes, ou como aprender a ver de outra forma". Op. cit.

${ }^{30}$ Refiro-me ao fato de que esta pesquisa de pós-doutorado se deu em torno da articulação entre questões éticas e estéticas no pensamento da desconstrução. Em Derrida, a literatura aparece como estratégia de questionamento da verdade pretendida pela tradição filosófica. Sem essência ou identidade, a literatura apontará a potência de ficção e de indeterminação de todo texto, inclusive e sobretudo o filosófico, desempenhando também função estratégica no pensamento ético de Derrida.

${ }^{31}$ MICHAUD, G. "Psicanálise, literatura, desconstrução: o impossível em partilha". Op. cit. Grifo meu.

32 Mais sobre Esporas: os estilos de Nietzsche em RODRIGUES, C. Duas palavras para o feminino: hospitalidade e responsabilidade. Sobre ética e política em Jacques Derrida. Rio de Janeiro: NAU /Faperj, 2013.

${ }^{33}$ DERRIDA, J. "O carteiro da verdade". In: O cartão-postal: de Sócrates e Freud e além. Tradução de Ana Valéria Lessa e Simone Perelson. Rio de Janeiro: Civilização Brasileia, 2007, p. 483.

${ }^{34}$ Ibidem, p. 484.

${ }^{35}$ Idem. Gramatologia. Tradução de Miriam Chnaiderman e Renato Janine Ribeiro. São Paulo: Perspectiva, 2004, p. 14.

${ }^{36}$ Idem. "O carteiro da verdade". Op. cit., p. 516.

${ }^{37}$ Idem. A estrutura e a diferença. Tradução de Maria Beatriz Marques Nizza da Silva, Pedro Leite Lopes e Pérola de Carvalho São Paulo: Perspectiva, 2009, p. 408.

${ }^{38}$ Trabalho com a proposição de que a crítica de Derrida ao estruturalismo se dá na percepção de que este seria um pensamento ainda preso a um ideal de fundamento, cuja função seria garantir certas estruturas que totalizam um campo no qual o jogo de referências, sempre sob controle, parte de uma origem e remete ao centro como lugar próprio, orientador. No estruturalismo, o centro da estrutura faria função de fundamento. No parentesco, por exemplo, o tabu do incesto pensado por Lévi-Strauss como universal estaria no centro e cumpriria função de fundamento. Na estrutura da linguística de Saussure, com a qual Derrida também discutirá, o centro estaria na noção de signo, com sua ligação arbitrária entre significante e significado. A união entre os dois - como as duas faces de uma folha de papel - subtrai o jogo da linguagem e o limita. Em Lacan, o lugar privilegiado do significante falo faria esta função de fundamento, organizando a estrutura e criando 
limitações ao jogo masculino/feminino. RODRIGUES, C. "Antígona - lei do singular, lei no singular”. In: Revista Sapere Aude, v. 3,n.5. Belo Horizonte, 2012.

${ }^{39}$ HURST, A. Derrida vis-à-vis Lacan. Interweaving Deconstruction and Psychoanalysis. Nova York: Fordham University, 2008, p. 373.

${ }^{40}$ SAFATLE, V. "Être juste avec Freud". Op. cit., p. 402.

${ }^{41}$ Ibidem.

42 HURST, A. Op. cit.

${ }^{43}$ BADIOU, A.; ROUDINESCO, E. Jacques Lacan, passado presente. Tradução Jorge Bastos. Rio de Janeiro: Difel, 2012, p. 30.

${ }^{44}$ Esta palavra - impossível - é uma das muitas em comum entre Lacan e Derrida. A rigor, poderse-ia dizer que, para ambos os pensadores, só o impossível acontece, porque o impossível é o real, e sempre se manterá como impossível. 